\title{
Pendidikan Karakter pada Peserta Didik di Masa Pandemi Covid-19 Berbasis Keluarga
}

\author{
Agus Setiawan \\ Pendidikan IPS, Program Pascasarjana Universitas PGRI Yogyakarta \\ Email: sapeagussetiawan@gmail.com
}

\begin{abstract}
Education during the Coronavirus Disease 2019 pandemic has hampered the process of character development for students in schools. The provision of education has been transferred through an online system or study from home, so that the role of the parents is very crucial in supervising and educating their children, especially in instilling character in the family sphere. Character education is very important to learn in order to instill in children so that they can live better and have character with values based on the points of Pancasila's values. In this study using a literature review approach to review character education in students during pandemic on family-based environment. Parents who are in family institutions serve as the teachers at home and have a strategic role and the main thing is to educate students when learning online at home. Schools, teachers, parents, and the community must work together in an effort to shape the character of students to create harmony in life. Which is why it takes good coordination between parents, teachers, schools, and the community as a supporting factor in order to shape the character of students.
\end{abstract}

\section{Keyword: Character, Students, Family}

Abstrak. Pendidikan pada masa Pandemi Covid-19 telah menghambat proses pembentukan karakter peserta didik disekolah. Penyelenggaraan pendidikan telah dialihkan melalui sistem daring (study from home) sehingga peran orang tua sangat sentral dalam mengawasi dan mendidik anakanaknya terutama dalam menanamkan karakter dalam lingkup keluarga. Pendidikan karakter merupakan pembelajaran yang penting untuk ditanamkan pada anak agar dapat hidup lebih baik dan memiliki karakter dengan nilai-nilai yang berlandaskan sesuai dengan butir-butir pancasila. Dalam studi ini menggunakan pendekatan kajian kepustakaan (literature review) guna mengulas pendidikan karakter pada peserta didik di masa pandemi berbasis keluarga. Orang tua yang berada dalam lembaga keluarga sebagai guru dirumah memiliki peran strategis dan yang utama untuk mendidik peserta didik saat pembelajaran daring dirumah. Sekolah, orang tua, dan masyarakat harus bekerjasama dalam upaya pembentukan karakter peserta didik untuk mewujudkan keharmonisan dalam kehidupan. Sehingga dibutuhkan koordinasi yang baik antara orang tua, sekolah, dan masyarakat sebagai faktor pendukung dalam pembentukan karakter peserta didik.

\section{Kata Kunci: Pendidikan Karakter, Peserta Didik, Keluarga}

\section{PENDAHULUAN}

Pandemi Covid-19 telah menghambat proses laju perkembangan kehidupan bangsa Indonesia mulai dari sektor ekonomi, politik, hubungan sosial, dan pendidikan. Satuan pendidikan menjadi salah satu sektor yang terkena dampak dari adanya wabah Covid-19 dengan terhambatnya proses pembelajaran bagi peserta didik secara langsung di sekolah. Namun, proses pembelajaran bagi anak-anak harus terus diselenggarakan walau tidak dilaksanakan seperti biasanya. Proses pembelajaran bagi anak-anak tidak harus dilaksanakan dengan bertatap muka sebagaimana semestinya, namun bisa diganti pembelajaran daring atau online dengan berbagai macam aplikasi seperti, whatsApp (WA), google classroom, zoom meting dan sejenisnya. Oleh karena itu, pemerintah yang diwakili oleh kementerian pendidikan dan kebudayaan mengeluarkan surat edaran No. 369/MPK.A/HK/ 2020 tentang pelaksanaan proses pembelajaran melalui non tatap muka atau daring pada masa darurat wabah pandemi 
Covid-19, langkah tersebut merupakan upaya pemerintah untuk memenuhi hak peserta didik untuk dapat menikmati pendidikan dan mencegah penularan penyakit yang semakin tinggi (Kemendikbud, 2020). Dengan demikian kegiatan proses belajar dan pembelajaran dilakukan di rumah dengan didampingi oleh orang tua masing-masing dan dengan diisi tentang pendidikan karakter bagi anak sehingga orang tua perlu melakukannya secara optimal. Pendidikan karakter diharapakan mampu memberikan dampak baik bagi kemajuan kehidupan masyarakat bangsa dan negara dalam menjawab degradasi moral pada remaja terutama pada peserta didik. Pendidikan karakter menjadi sebuah langkah yang harus ditempuh dalam membentuk karakter peserta didik yang berbudi pekerti luhur. Helmawati (2017) menjelaskan bahwa pendidikan karakter dapat dipercaya mampu mengarahkan individu kearah yang lebih baik menuju keberhasilan dan kemajuan bagi bangsa maupun negara. Pembentukan karakter bukan saja diawali oleh Rasulullah Saw dengan melalui perubahan peradaban, namun para ilmuwan barat pun menyadari bahwa pendidikan karakter berperan penting dalam mempertahankan eksistensi suatu bangsa dan negara.

Undang-undang RI Nomor 20 Tahun 2003 tentang sistem pendidikan nasional pada pasal 3 dijelaskan bahwa pendidikan nasional berfungsi mengembangkan kemampuan dan membentuk watak serta peradaban bangsa yang bermartabat dalam rangka mencerdaskan kehidupan bangsa dan bertujuan untuk berkembangnya potensi peserta didik supaya menjadi manusia yang beriman memiliki kekuatan religius, kepribadian, pengendalian diri, kecerdasan, akhlak mulia serta keterampilan yang dibutuhkan baik dalam kehidupan bermasyarakat maupun berbangsa dan bernegara. Pendidikan karakter merupakan suatu sistem penanaman nilai-nilai yang berbudi pekerti luhur yang berlandaskan pada nilai kebudayaan yang bersumber pada butirbutir pancasila. Beberapa tahun terakhir pemerintah gencar mengumumkan pentignya pendidikan karakter bagi setiap anak bangsa dalam meminimalisir perilaku-perilaku yang tidak sesuai dengan karakter bangsa.

Pendidikan karakter diterapkan mulai dari satuan pendidikan dasar sampai pada jenjang yang lebih tinggi yaitu perguruan tinggi untuk lebih menguatkan karakter bangsa. Peraturan Presiden Nomor 87 Tahun 2017 tentang penguatan pendidikan karakter bertujuan untuk menumbuhkan karakter pribadi bangsa yang berbudaya melalui penguatan nilai-nilai karakter yang bersumber dari nilai luhur budaya bangsa Indonesia. Merupakan salah satu upaya pemerintah dalam melakukan penguatan pendidikan karakter dengan melibatkan satuan pendidikan, sekolah, masyarakat, dan keluarga. Berdasarkan kondisi saat ini sekolah belum sepenuhnya mampu membentuk karakter peserta didik dikarenakan pembelajaran masih bersifat pada ranah pengembangan pengetahuan akademis namun belum benarbenar mampu menerapkan pendidikan karakter secara maksimal.

Setiawan (2013) menjelaskan bangku pesekolahan belum sepenuhnya mampu menghasilkan keluaran pengembangan kecerdasan moral para peserta didik, karena tumbuhnya budaya verbalistik dalam proses pembelajaran yang lebih cenderung mengajarkan pendidikan moral pada sebatas tekstual. Artinya pendidikan karakter menjadi sangat penting untuk diterapkan secara aktif sebagai esensi pengembangan dan pembentukan kecerdasan moral. Nurwahyuni (2019) penyelenggaraan pendidikan perlu direkonstruksi ulang untuk dapat menghasilkan generasi yang memiliki karakter mulia dan berkualitas yang siap menghadapi tantangan masa depan yang banyak dengan masalah. Banyaknya tindakan kriminalitas seperti kekerasan orang tua terhadap anak, guru terhadap murid, murid terhadap guru, dan kekerasan teman sebaya yang bermunculan menunjukan rendahnya penerapan pendidikan karakter pada masing-masing lembaga pendidikan. Pendidikan masih belum mampu menjadi sebagai agent of cange yang merubah dan membentuk individu menjadi lebih baik. Oleh karena itu, pendidikan karakter perlu menjadi perhatian serius dan kerja sama yang 
baik bagi seluruh stakeholder untuk saling melakukan koordinasi dalam upaya pembentukan karakter. Wibowo (2016) mengatakan belum ada kerjasama yang baik antara sekolah, orang tua peserta didik, dan masyarakat sehingga terkesan berjalan sendirisendiri dalam pembentukan karakter anak. Misalnya, di sekolahnya sudah ada pendidikan karakter yang diselenggarakan namun keluarga dan masyarakat justru mengikis nilainilai yang sudah diajarkan saat jam sekolah. Lingkungan keluarga yang secara substansialnya menjadi tempat tumbuh suburnya nilai-nilai karakter yang berbudi luhur berubah menjadi tempat kekerasan yang mengekang kebebasan berinovatif dan berkreativitas. Pola asuhan yang kurang baik tentu akan berdampak buruk bagi pertumbuhan maupun perkembangan peserta didik kedepannya begitupun sebaliknya. Untuk itu, pola asuh dalam keluarga harus dilaksanakan secara maksimal melalui pembiasaa, keteladanan, dan dengan kebudayaan serta nilai keagamaan.

Pendidikan karakter harus dipahami oleh setiap individu, baik bagi calon orang tua maupun yang sudah menyandang status sebagai orang tua. Setiap orang tua masingmasing memiliki tanggungjawab dalam menyelenggarakan pendidikan karakter dalam ruang lingkup keluarga bagi setiap anggota keluarganya. Penelitian ini, bertujuan untuk menjelaskan tentang pendidikan karakter pada peserta didik dimasa pandemi covid-19 berbasis keluarga. Penyelenggaraan pendidikan di satuan pendidikan sebagian besar di tiap daerah telah memberlakukan pembelajaran daring atau online. Hal ini harus disikapi dengan baik dan secara tepat, sebab proses pembinaan dan pendidikan karakter harus terus berjalan pada peserta didik untuk dapat membentuk karakter yang bermoral, berbudi pekerti luhur dan religius.

\section{METODE}

Desain dalam penelitian ini menggunakan metode penelitian kepustakaan atau kajian literatur. Penggunaan metode ini terkait dengan sitausi pandemi Covid-19 yang membatasi peneliti dalam pengambilan data.
Penelitian kepustakaan merupakan penelitian yang sumber data-datanya berasal dari berbagai literatur perpustakaan, baik berupa buku, kamus, dokumen, jurnal dan lain sebagainya. Dari berbagai literatur tersebut dapat menemukan, mengungkapkan, mengembangkan dan menguji kebenaran konsep, teori, dan pemikiran seorang tokoh sehingga perlu dilakukan kajian terhadap literatur yang sesuai dengan topik penelitian (Harahap, 2014).

Adapn analisis data dilakukan dengan analisis deskriptif yaitu menguraikan secara sistematis dari data yang di peroleh, selanjutya diberikan pemahaman dan penjelasan segingga dapat dipahami pembaca. Penelitian ini menggunakan sumber data sekunder, seperti jurnal, website, dan buku-buku yang berkaitan dengan pendidikan karakter. Dalam penelitian ini akan mendiskripsikan tentang pendidikan karakter pada peserta didik di masa pandemi Covid-19 berbasis keluarga.

\section{HASIL DAN PEMBAHASAN}

Hendriana \& Jacobus menjelaskan bahwa character berasal dari bahasa Yunani yaitu charassein yang berarti melukis, menggambar, memahat batu atau metal, berangkat dari pengertian tersebut charakter diartikan sebagai sebuah tanda atau ciri khas, sejalan dalam kamus besar bahasa Indonesia (KBBI) karakter memiliki arti akhlak, budi pekerti, sifat yang menjadi ciri khas masing-masing individu. Agboola \& Tsai (2012) mendefinisikan pendidikan karakter sebagai disiplin ilmu yang dikembangkan untuk mengoptimalkan perilaku karakter etis siswa. Sedangkan Lickona (2003) mendefinisikan bahwa karakter terdiri dari 3 landasan yaitu merupakan perasaan moral, pengetahuan moral, dan tindakan moral yang saling berhubungan. Dari penjelasan tersebut karakter dapat diidentikan dengan akhlak yang merupakan nilai-nilai perilaku secara universal dan diartikan sebagai ciri khas perilaku moral individu baik bertutur kata maupun dalam bentuk tindakan yang berhubungan dengan dirinya, sesama manusia, dan lingkungan alam serta terhadap Tuhan yang Maha Esa sebagai pencipta. Dengan demikian karakter 
melahirkan sebuah ide gagasan tentang penanaman pendidikan karakter baik dalam ruang lingkup keluarga, pendidikan formal, dan pendidikan non formal serta meliputi seluruh lapisan kehidupan.

Helmawati (2017) adapun yang menjadi tujuan dari pendidikan karakter yaitu untuk menyempurnakan akhlak, dapat menjadikan manusia yang berakhlak mulia, manusia yang beradab dan bermartabat dengan melalui olah perasaan, akal dan raganya secara bersamaan. Supranoto (2015) pendidikan karakter bangsa bertujuan untuk mengembangkan karakter bagi setiap individu untuk mengembangkan potensi dasar, berpikir lebih baik, berperilaku baik dalam kehidupan serta untuk membangun dan memperkokoh perilaku bangsa yang multikultural agar dapat hidup rukun dalam perbedaan yang sesuai dengan nilai luhur pancasila sehingga menjadi peradaban nasional yang menjadi contoh bagi bangsa di seluruh dunia. Oleh karena itu tujuan pendidikan karakter harus dapat dilaksanakan dengan penuh kesadaran dan terencana untuk keberlangsungan kemajuan bangsa dimasa yang akan datang. Pendidikan karakter dapat ditanamkan dengan melalui pendidikan yang terus berkelanjutan, baik dalam ruang lingkup pendidikan formal (sekolah), non forman (lingkungan sosial), dan informal (lingkungan keluarga).

Penguatan pendidikan karakter tertuang dalam Permendikbud Nomor 20 Tahun 2018 yaitu dengan menyelenggarakan pendidikan karakter dengan menanamkan sikap religius, nasionalisme, kemandirian, gotong royong, dan integritas yang berlandaskan pancasila. Sehingga penguatan pendidikan karakter perlu direncanakan dalam kurikulum pendidikan. Dalam pendidikan formal disatuan pendidikan ada yang namanya kurikulum yang merupakan landasan penyelenggaraan rencana dan proses pembelajaran yang di dalamnya memuat tentang pendidikan karakter untuk dijadikan sebagai acuan bagi sekolah terutama guru dalam mengajar peserta didik disekolah. Harun (2013) menjelaskan bahwa dengan melalui kurikulum 2013 berbasis kompetensi dan karakter, pemerintah mendorong guru agar lebih berperan memberikan pendidikan karakter pada peserta didik apalagi diera globalisasi saat ini dapat membawa dampak negatif maupun dampak positif bagi keberlangsungan kehidupan. Namun orang tua/keluargapun memiliki peranan yang amat besar dalam pembentukan karakter anak, semua orang terlebih dalam ruang lingkup keluarga disebabkan anak-anak memiliki banyak waktu di rumah sehingga menjadikan orang tua sebagai pendidik yang utama dalam mengembangkan potensi anak dan mendidik untuk membentuk karakter anak.

Pendidikan karakter dalam ruang lingkup keluarga sangat perlu ditempuh untuk membentuk karakter anak dengan mendidik dan mengontrol anak dirumah terlebih dimasa pandemi Covid-19 saat ini yang melakukan pembelajaran online di rumah masing-masing. Satriah (2011) melakukan penelitian di 65 lembaga pendidikan anak usia dini di Jawa Barat yang menerapakan pendidikan karakter, menunjukan hasil bahwa orang tua masih banyak yang belum paham tentang pola pengasuhan dalam penerapan pendidikan karakter pada anak sehingga terjadi hambatan bagi pihak sekolah untuk mengefektifkan penyelengaraan pendidikan karakter dalam membentuk karakter peserta didik di sekolah. Pendidikan karakter di sekolah akan maksimal apabila didukung dengan pendidikan karakter dalam keluarga karena orang tua merupakan faktor penunjang dalam keberhasilan pembentukan karakter anak. Menurutnya penerapan pendidikan karakter disamping mempersiapkan anak-anak berkarakter berbudi pekerti luhur dan berakhlak mulia, juga merupakan sebagai salah satu cara dalam mengantisipasi dan menyelesaikan persoalan dalam kehidupan bermasyarakat.

Penelitian yang dilakukan oleh Ni'mawati, Handayani \& Hasanah (2020) tentang pengelolaan manajemen pendidikan karakter menunjukan hasil bahwa ada 3 cara yang perlu ditempuh agar pendidikan karakter efektif diterapkan pada peserta didik, salah satunya dengan melakukan kerja sama dengan orang tua peserta didik, hubungan dengan orang tua peserta didik harus dierat, dijalin dengan baik dengan terus membangun 
koordinasi terkait dengan perkembangan peserta didik dalam upaya pembentukan. Asikin (2018) dalam penelitiannya mengatakan bahwa orang tua merupakan pondasi utama dalam penanaman pendidikan karakter bagi anak, orang tua sebagai pendidik dalam lembaga pendidikan keluarga perlu melakukan pengajaran, pembiasaan, peneladanan, pemotivasian, dan melalui penegakan aturan untuk mengembangkan dan membentuk karakter anak. Lebih lanjut dikatakan bahwa pendidikan karakter harus terus dilaksanakan dengan baik secara disiplin dan berkelanjutan sehingga lembaga lingkungan keluarga, sekolah dan masyarakat sama-sama memiliki peran dan tanggung jawab. Untuk itu, perlu melakukan kerja sama yang baik agar dapat membentuk anak berkarakter akhlak mulia dalam menjalani kehidupan.

Penelitian yang dilakukan oleh Safitri (2017) menjelaskan bahwa dalam lingkungan keluarga menjadi tempat yang sangat strategis dan memiliki peran yang utama dalam penanaman pendidikan karakter dengan berbasis kesadaran diri. Dengan kesadaran diri dapat memberikan dampak bagi anggota keluarga. Penanaman pendidikan karakter dilakukan dalam aktivitas sehari-hari dengan memberikan contoh teladan seperti melakukan pekerjaan rumah secara bersama-sama yang mencerminkan nilai atau karakter gotong royong. Sehingga untuk mewujudkan anggota keluarga yang berkarakter diperlukan sosok kepala keluarga yang memiliki sikap bijaksana yang dapat memberikan teladan dalam ucapan maupun tindakan, sehingga dapat menjadi sebuah metode dalam menumbuhkan kesadaran diri untuk membentuk karakter sebagai pedoman dalam kehidupan. Dengan menjadi orang tua yang baik dapat berpengaruh dalam perkembangan anak dengan selalu menghargai setiap apa yang diusahakan anak-anak dalam mengembangkan potensi untuk mencapai kabaikan dan kemajuan dalam dirinya.

Simarta (2017) mengemukakan bahwa keluarga memiliki peran dalam pengembangan karakter peserta didik, ketika anak diperhatikan kebaradaannya diterima dan diakui serta kebutuhan pokoknya dipenuhi oleh orangtua, maka karakter anak akan dapat tumbuh dan berkembang dengan baik. Pendidikan karakter berbasis keluarga dapat memberi manfaat bagi karakter bangsa. Oleh karenanya keluarga harus dijadikan sebagai school of love, sebagai penggerak pendidikan karakter sehingga pola pengasuhan yang dilakukan oleh orang tua sebagai pendidik di rumah perlu memiliki pengetahuan tentang nilai-nilai karakter. Lickona, terjemahan, Wamaungo \& Zien (2016) pengasuhan memiliki dampak besar pada kemampuan anak mengerjakan tugas sekolah, pertumbuhan moral dan perilaku. Penetapan standar tentang apa yang diajarkan oleh orang tua untuk menjadikan anak disiplin dalam segala hal. Oleh karenannya pola pengasuhan anak perlu di jalankan secara maskimal dengan melihat dan mempertimbangkan perkembangan yang sesuai dengan tingkatan dan kebutuhan anak.

Sutirna (2013) menjelaskan bahwa di dalam jaman yang semakin moderen, memahami perkembangan anak merupakan faktor terpenting agar dapat difasilitasi dan dibimbing secara tepat sehingga anak dapat membentuk karakter yang mampu menyelesaikan masalah yang sedang dihadapinya. Apabila proses perkembangan anak tidak dipelajari dan dipahami oleh setiap stakeholder, mulai dari orang tua, sekolah, pemeritah, dan masyarakat maka akan berdampak buruk pada perkembangan sikap dan perilaku anak dalam kehidupan sosial. Dengan demikian untuk menjadi guru yang bermutu dan profesional, setiap orang yang medidik dan mengajar anak perlu memahami terlebih dahulu fase perkembangan peserta didik. Orang tua sebagai orang yang utama didalam keluarga harus mampu melihat aspekaspek perkembangan anak dalam memberikan pengajaran dan pendidikan dalam membentuk karakter peserta didik. Desmita (2017) ada 3 macam aspek perkembangan. Pertama, perkembangan aspek fisik yang disebut dengan pertumbuhan biologis (biological growth) yaitu perubahan yang meliputi dalam tubuh seperti pertumbuhan otak, organ indra indrawi, dan sistem saraf. Perubahan dalam cara individu dalam memfungsikan tubunnya 
seperti perkembangan motorik dan seksual. Perubahan dalam kemampuan fisik seperti penurunan penglihatan, fungsi jantung dll. Kedua, aspek Kognitif yaitu perkembangan yang berkaitan dengan pengetahuan, perkembangan yang berhubungan dengan perubahan mental, persepsi, keterampilan berbahasa, pemikiran, dan analisis atau semua proses perkembangan psikologis tentang bagaimana cara seseorang belajar dalam memperoleh pengetahuan. Ketiga, aspek Psikosional merupakan proses yang meliputi perubahan emosi dan kepribadian peserta didik dalam berhubungan dengan orang lain, yaitu kemampuan indvidu dalam menyesuaikan diri dengan lingkungan sekitarnya dengan cakupan yang lebih luas tanpa menghilangkan jati dirinya. Ketiga aspek tersebut merupakan landasan bagi setiap pendidik terutama dalam hal ini orang tua sebagai pendidik yang berperan membentuk karakter anak dalam lingkungan keluarga. Sehingga tujuan pembelajaran pendidikan karakter di masa pandemi Covid-19 dapat mencapai keberhasilan seperti yang dicita-citakan. Intania \& Sutama (2020) menilai bahwa pendidikan karakter dalam pembelajaran di masa pandemi memiliki peran dalam mengembangkan karakter siswa yang baik dan dapat diimplementasikan dalam kehidupan sosial. Selain itu, pendidikan karakter di era pandemi Covid-19 telah mendorong kemandirian belajar peserta didik dan membentuk karakter tanggung jawab terhadap materi dan tugas-tugas pembelajaran yang diberikan oleh guru melalui pembelajaran daring/online. Sejalan dengan temuan Suasthi \& Suadnyana (2020) dalam penelitiannya tentang membangun karakter "genius" pada peserta didik di masa pandemi Covid-19 dengan melakukan pembelajaran dari rumah berbasis daring dapat berpengaruh pada karakter religius, kecerdasan moral, dan sikap sosial yang dapat menjunjung tinggi nila-nilai moral dalam kehidupan, sikap empati berkembang dengan peduli pada sesama dan terbiasa beraktivitas dengan menerapkan protokol kesehatan sehingga anak tumbuh dengan pola hidup sehat. Selain itu, pembelajaran daring dari rumah sebagai bentuk menerapkan kebijakan pemerintah dalam memenuhi hak peserta didik untuk terus dapat menikmati pendidikan, terutama dalam penanaman pendidikan karakter.

Tugas mendidik anak bukan hanya dipelajari oleh para guru akan tetapi orang tua sebagai pendidik yang utama dalam lingkungan keluarga sama-sama perlu memahami strategi dalam mengajar anak agar dapat mendidik anak secara baik dan tepat. Menurut Lickona et al. (2007) terdapat beberapa klasifikasi peran pendidik yaitu, pertama dalam proses pembelajaran pendidik perlu melakukan diskusi dan mempunyai inisiatif dalam proses pendidikan karakter. Kedua, seorang pendidik mempunyai tanggung jawab dan menjadi role model yang memiliki nilai-nilai moral dan mempunyai kemampuan dalam mempengaruhi peserta didik. Ketiga, tugas pendidik harus mampu memberikan pengetahuan mengenai karakter peserta didik dapat tumbuh melalui sikap gotong royong atau kerja sama dan demokratis dalam proses pengambilan keputusan. Keempat, pendidik perlu mengevaluasi karakter peserta didik melalui penilaian rutin mengenai permasalahan moral yang terjadi dalam kehidupan bermasyarakat dan kelima pendidik secara berkala harus menerapkan dan menjelaskan berbagai nilai-nilai karakter yang baik dan buruk sehingga peserta didik dapat membedakan antara yang baik dan buruk. Orang tua perlu berkolabarasi dengan baik bersama dengan pihak sekolah yaitu dengan tenaga pendidik (guru) dalam upaya mendidik anak-anak. Peran aktif orang tua menjadi faktor pendukung untuk keefektifan proses pembelajaran yang diselenggarakan di rumah dan yang tak kalah penting mengenai pembentukan karakter anak.

Penelitian yang dilakukan oleh Rahmah (2017) Mengemukakan bahwa pendidikan keluarga merupakan salah satu pendidikan yang dapat berfungsi untuk mencerdaskan peserta didik (anak). Di dalam ruang lingkup keluarga orang tua memberikan pengetahuan dan praktik mengenai pergaulan dalam lingkungan, tentang budaya masyarakat, dan yang sangat penting tentang nilai-nilai keagamaan melalui pengamalan setiap hari 
sekaligus pengalaman dan pengetahuan hidup yang telah didapatkan. Sedangkan penelitian yang dilakukan Trisnawati \& Sugito (2020) tentang pendidikan anak dalam keluarga Era Covid-19 semakin mempertegas peran orang tua dalam membentuk karakter anak. Dalam hasil penelitiannya menjelaskan orang tua menjadi fasilitator sekaligus guru pada pembelajaran anak di rumah dengan memberikan fasilitas belajar, melakukan pendampingan belajar pada anak seperti membantu menyelesaikan tugas, belajar pada lingkungan sekeliling, dan memberikan pembelajaran tentang Covid-19 serta memberikan rewards.

Purandina \& Winaya (2020) dalam tujuan penelitiannya yang ingin mengetahui aktivitas belajar di rumah mampu mengembangkan nilai-nlai karakter peserta didik. Menjelaskan bahwa sewalaupun Covid19 menghambat berbagai aktivitas dan memperburuk keberlangsungan kehidupan tak terkecuali di sektor pendidikan. Namun disisi lain, bisa menjadi situasi yang baik dalam mengembangkan pendidikan karakter anak dilingkungan keluarga. Di masa pembelajaran online yang dilakukan di rumah dapat mengembangkan beberapa nilai karakter yaitu nilai karakter religius, niali karakter disiplin, nilai karakter kreatif, nilai karakter mandiri, dan nilai karakter tanggung jawab serta nilai karakter rasa ingin tahu. Berkembangnya nilainilai karakter anak merupakan hasil kerjasama antara orang tua dan guru dalam melakakan aktivitasi positif, berinteraksi dan berkoordinasi dalam membimbing dengan penuh kesabaran. Dengan demikian dengan membangun kerjasa sama, dengan terus saling berkoordinasi satu sama lain terkait dengan perkembangan anak dapat menjadi langka preventif untuk mencapai keberhasilan demi mewujudkan peradaban sosial yang damai dan maju.

\section{KESIMPULAN}

Pendidikan karakter dimasa pandemi Covid-19 membutuhkan peran orang tua yang cukup sentral dan berperan aktif dalam mendidik anak dalam lingkup keluarga selain guru itu sendiri. Pembelajaran yang dilakukan melalui daring saat ini mengharuskan orang tua untuk lebih berperan secara optimal dalam pembentukan karakter anak selama menjalani pembelajaran di rumah. Orang tua memiliki banyak kesempatan sehingga rumah sebagai pengganti ruangan sekolah dapat menjadi sarana yang cukup efektif dalam mendidik anak. Keluarga menjadi lingkungan yang efektif dalam penyelenggaraan pendidikan karakter bagi anak-anaknya untuk membentuk karakter peserta didik yang mandiri, bertanggung jawab dan mengembangkan keterampilan serta pengetahuannya dengan secara maksimal supaya mampu menjadi anak yang memiliki karakter kepribadian baik yang dapat menciptakan keharmonisan dan kemajuan dalam kehidupan. Namun di sisi lain, peran sekolah dan masyarakat pun merupakan bagian yang tidak dapat dipisahkan dalam menunjang keberhasilan pembentukan karakter anak. Kolaborasi dapat menjadi sebuah pembelajaran yang dapat membantu perkembangan peserta didik untuk mengembangkan pengetahuan (kognitif) dan membentuk karakter kepribadian (afektif). Dengan demikian kerjasama antara pemerintah dalam hal ini satuan pendidikan dengan masyarakat, dan keluarga (orang tua) peserta didik merupakan hal yang tidak boleh diabaikan demi mencapai keberhasilan dalam membentuk karakter peserta didik.

\section{DAFTAR PUSTAKA}

Agboola, A., \& Tsai, K. C. (2012). Bring Character Education Into Classroom. European Journal of Educational Research. Vol. 1, No. 2, pp. 163-170.

Asikin, Ikin. (2018). Pengembangan Model Pendidikan Karakter Di Lingkungan Keluarga. Jurnal Pendidikan Islam. Vol. 7, No. 1, pp. 434-444.

Desmita. (2017). Psikologi Perkembangan peserta didik. Bandung: PT Remaja Rosdakarya.

Harahap, Nursapia. (2014). Penelitian Kepustakaan. Jurnal Iqra. Vol. 08, No. 01, pp. 68

Harun, C. Z. (2013). Manajemen Pendidikan Karakter. Jurnal Pendidikan 
Karakter. Vol. 3, No. 3, pp. 302-308.

Helmawati. (2017). Pendidikan karakter sehari-hari. Bandung: PT Remaja Rosdakarya.

Hendriana, C.E., \& Jacobus, A. (2016). Implementasi Pendidikan Karakter Di Sekolah Melalui Keteladanan Dan Pembiasaan. Jurnal Pendidikan Dasar Indonesia. Vol. 1, No, 2, pp. 25-29.

Intania, E. V. \& Sutama (2020). The Role Of Character Education In Learning During the COVID-19 Pandemic. Jurnal Penelitian Ilmu Pendidikan. Vol. 13, No. 2, pp. 129-136.

Kemendikbud. (2020). Panduan Penyelenggaraan Pembelajaran Pada Tahun Ajaran 2020/2021 dan Tahun Akademik 2020/2021 di Masa Pandemi CoronaVirus Disease 2019 (Covid-19). Kementerian Pendidikan dan Kebudayaan Indonesia.

Kementerian Pendidikan Kebudayaan Republik Indonesia. (2017).

Penguatan Pendidikan Karakter Jadi Pintu Masuk Pembenahan Pendidikan Nasional. https://www.bappenas.go.id/id/ berita-dan-siaran-pers/narasitunggal-penguatan- pendidikankarakter-jadi-pintu-masukpembenahan-pendidikan-nasional/.

Lickona, T., Schaps, E \& Lewis, C. (2007). Eleven Principles of Effective Character Education,

Washington, DC. USA: Character Education Partnership.

Lickona, Thomas. (2003). My Thought About Character, London: Cornell University Press.

Ni'mawati., Handayani, F., \& Hasanah, A. (2020). Model Pengelolaan Pendidikan Karakter Di Sekolah Pada Masa Pandemi. Jurnal Studi Islam. Vol. 1, No. 2, pp. 145-156. Nurwahyuni, Annisa. (2019). Literature Review: Perbedaan Pendidikan
Karakter Yang Diterapkan

Pada Generasi X, Y Dan Z. Prosiding Seminar Nasional \& Call Paper Psikologi Pendidikan.

Universitas Surabaya, pp. 66-75.

Peraturan Menteri Pendidikan dan kebudayaan Republik Indonesia Nomor 20 Tahun 2018. Penguatan Pendidikan Karakter pada Satuan Pendidikan Formal. Kementerian

Pendidikan Kebudayaan. 7 Juni 2018. Lembaran Negara Republik Indonesia Tahun 2018 Nomor 194.

Purandina, I.P.Y., \& Winaya, I.M.A. (2020). Pendidikan Karakter Di Lingkungan Keluarga Selama Pembelajaran Jarak Jauh Pada Masa Pandemi Covid-19. Jurnal Ilmu

Pendidikan. Vol. 3, No. 2, pp. 270290.

Rahmah, S. (2017). Peran Keluarga dalam Pendidikan Akhlak. AL-Hiwar: Jurnal Ilmu dan Tekhnik Dakwah. Vol. 4, No. 6.

Safitri, M.R. (2017). Penanaman Pendidikan Karakter Berbasis Kesadaran Diri dalam Lingkungan Kelarga. Prosiding Seminar Nasional Lembaga Kebudayaan, pp. 126-131.

Satriah, Lilis. (2011). Pendidikan Karakter Dalam Keluarga. Jurnal Kependidikan dan Kemasyarakatan. Vol. 9, No. 1, pp. $42-54$.

Setiawan, Deny. (2013). Peran Pendidikan Karakter Dalam Mengembangkan Kecerdasan Moral. Jurnal Pendidikan Karakter. Vol. No. 1, pp. 53-63.

Simarnata, H.D. (2017). Pendidikan Karakter Berbasis Keluarga: Sebuah Perspektif. Jurnal Pendidikan Penabur. Vol. No. 9, pp. 92-100.

Suasthi, G.A. \& Suanyana, I.B.P.E. (2020). Membangun Karakter "Genius" Anak Tetap Belajar Dari Rumah Selama Pandemi Coivid-19 Pada Sekolah Suta Dharma Ubud Gianyar. 
Jurnal Ilmu Pendidikan. Vol. 3, No. 3, pp. 431-151.

Supranoto, H. (2015). Implementasi Pendidikan Karakter Bangsa Dalam Pembelajaran SMA. Jurnal Pendidikan Ekonomi UM Metro. Vol. 3, No. 1, pp. 36-49.

Sutirna. (2013). Perkembangan Dan Pertumbuhan Peserta didik. Yogyakarta: Andi Offset.

Trisnawati, Wahyu., \& Sugito. (2020). Pendidikan Anak dalam Keluarga Era Covid-19. Jurnal Obsesi. Vol. 5 No. 1, pp. 824-1021. 